\title{
Pengujian Performansi pada Simulator AC Water Chiller dengan Multiple Chilled Water
}

\author{
A.A. Krisna Wira Putra', I Wayan Sutarsa'2, I Wayan Widiantara ${ }^{3}$ \\ ${ }^{1}$ A.A. Krisna Wira Putra, Politeknik Negeri Bali, email: krisnawiraputra@pnb.ac.id \\ 2I Wayan Sutarsa, Politeknik Negeri Bali, email: wayansutarsa@pnb.ac.id \\ 3I Wayan Widiantara, Politeknik Negeri Bali, email: wayanwidiantara@pnb.ac.id
}

Submisi: 22 Agustus 2019; Penerimaan: 20 Mei 2020

\begin{abstract}
ABSTRAK
AC jenis Water Chiller merupakan AC dengan pendinginan tidak langsung (indirect contac), karena refrigeran sebagai media pendingin di dalam sistem refrigerasi digunakan untuk mendinginkan air (disebut chilled water). Kemudian 'chilled water' ini disirkulasikan oleh pompa sirkulasi air dingin (chilled water pump) ke FCU (Fan Coil Unit) atau AHU (Air Handling Unit). Pada alat inilah nantinya udara ruangan didinginkan oleh air dingin tersebut. FCU digunakan untuk mendinginkan udara ruangan yang berukuran kecil sedangkan untuk ruangan-ruangan besar dapat dilayani dengan $A H U$, dimana udara dingin dari AHU disalurkan ke ruangan yang akan dikondisikan melalui saluran udara (air duct).

Penelitian ini menggunakan metode eksperimen, dengan melakukan pengujian langsung pada perangkat praktikum simulator AC jenis water chiller (air conditioning water chiller) penunjang pembelajan di Laboratorium Tata Udara Program Studi Teknik Pendingin dan Tata Udara Jurusan Teknik Mesin Politeknik Negeri Bali. Pengujian ini dibuat untuk mengetahui lebih dalam tentang pengaruh jumlah pompa chilled water terhadap performansi simulator $A C$ water chiller dalam kegiatan praktikum mahasiswa. Hasil pengujian yang dilakukan menyimpulkan bahwa semakin besar laju aliran massa air maka ada kecenderungan daya kompresor yang dibutuhkan semakin besar dengan peningkatan daya sebesar $3.47 \%$, sedangkan COP (Coefficient of Performance) yang dihasilkan pada saat menggunakan dua pompa meningkat sebesar $6.25 \%$.
\end{abstract}

Kata Kunci : AC jenis water chiller; TXV (Thermostatic Expansion Valve); konsumsi daya kompresor; COP (Coefficient of Performance).

\section{PENDAHULUAN}

\section{Latar Belakang}

Semakin terasanya dampak pemanasan global, maka kenyamanan beraktifitas di dalam ruangan juga sangat dibutuhkan. Penataan udara pada umumnya menggunakan AC (Air Conditioning) yang digunakan untuk pengkondisian udara agar menimbulkan rasa nyaman bagi penggunanya. Teknologi tata udara sangat banyak dipergunakan dan dibutuhkan baik untuk keperluan industri, hotel, restoran, rumah tangga, sekolah, maupun universitas. Ruangan-ruangan yang berukuran luas akan membutuhkan sistem pendingin yang efisien, maka digunakanlah $A C$ jenis Water Chiller.

AC jenis Water Chiller merupakan $A C$ dengan pendinginan tidak langsung (indirect contact), karena refrigeran sebagai media pendingin di dalam sistem refrigerasi digunakan untuk mendinginkan air (disebut chilled water). Kemudian 'chilled water' ini disirkulasikan oleh pompa sirkulasi air dingin (chilled water pump) ke FCU (Fan Coil Unit) atau AHU (Air Handling Unit). Pada alat inilah nantinya udara ruangan 
didinginkan oleh air dingin tersebut. FCU digunakan untuk mendinginkan udara ruangan yang berukuran kecil, sedangkan untuk ruangan-ruangan besar dapat dilayani dengan $\mathrm{AHU}$, di mana udara dingin dari AHU disalurkan ke ruangan yang akan dikondisikan melalui saluran udara (air duct). Karena pengkondisian udara sentral (AC jenis water chiller) digunakan untuk kapasitas pendinginan yang besar dan menggunakan satu pompa yang dirangkai pada AC jenis water chiller pada kajian-kajian sebelumnya memperoleh nilai head yang kecil, sehingga tekanan pada sisi keluar FCU terlalu rendah. Pengujian ini akan mencoba menggunakan dua pompa yang dirangkai seri pada sistem FCU untuk memperoleh peningkatan nilai head. Hal ini juga akan diupayakan untuk mengetahui performansi terhadap pengaruh penggunaan TXV (Thermal Expansion Valve) dengan membandingkan penggunaan satu pompa dengan dua pompa yang dirangkai seri pada sistem FCU.

\section{Rumusan Masalah}

Permasalahan yang diharapkan dapat diselesaikan melalui pengujian ini yaitu Bagaimana pengaruh jumlah pompa chilled water terhadap performansi simulator AC water chiller?

Batasan masalah dalam pengujian ini hanya mencakup hal-hal yang berkaitan dengan pengaruh jumlah pompa chilled water terhadap performansi simulator AC water chiller.

Tujuan yang diharapkan dari pengujian ini adalah mengetahui pengaruh jumlah pompa chilled water terhadap performansi simulator AC water chiller.

Manfaat yang diharapkan dapat menambah pengetahuan dan wawasan mahasiswa mengenai pengaruh jumlah pompa chilled water terhadap performansi dan adanya pengembangan atau penyempurnaan peralatan praktikum di laboratorium Program Studi Teknik Pendingin dan Tata Udara, Jurusan Teknik Mesin Politeknik Negeri Bali.

\section{METODE PENELITIAN}

\section{Jenis Penelitian}

Pengujian ini menggunakan metode eksperimen, dengan melakukan pengujian langsung pada perangkat praktikum simulator AC jenis water chiller (air conditioning water chiller) di Laboratorium Tata Udara Program Studi Teknik Pendingin dan Tata Udara Jurusan Teknik Mesin Politeknik Negeri Bali.

Jenis pengujian ini adalah eksperimen, karena dilakukan dengan pengujian menggunakan satu pompa dan dua pompa yang dirangkai secara seri dengan menggunakan katup ekspansi ke alat pengujian yaitu simulator AC water chiller. Pengujian ini dirancang secara bertahap yang mencakup: persiapan, perancangan alat, modifikasi sistem, pengosongan, pemvakuman, tes kebocoran, dan pengisian. Proses pengosongan, pemvakuman, dan pengisian ini wajib dilakukan sebelum melakukan pengujian dimana langkah-langkah tersebut sangat menentukan dalam pengambilan data.

\section{Lokasi dan Waktu Pengujian}

Lokasi pengambilan data penelitian ini dilakukan di Laboratorium Tata Udara Jurusan Teknik Mesin Politeknik Negeri Bali karena terdapat peralatan yang lengkap, sehingga memudahkan dalam melakukan proses pengambilan data. Waktu yang digunakan dalam proses pengujian yang meliputi persiapan, pelaksanaan, dan 
penyusunan laporan kegiatan seperti

pada Tabel 1.

Tabel 1. Jadwal pelaksanaan

\begin{tabular}{|c|c|c|c|c|c|c|c|c|c|c|c|c|c|c|c|c|c|c|c|c|c|}
\hline \multirow{3}{*}{ No } & \multirow{3}{*}{ Uraian Kegiatan } & \multicolumn{20}{|c|}{ Waktu : Tahun 2018} \\
\hline & & \multicolumn{4}{|c|}{ Maret } & \multicolumn{4}{|c|}{ April } & \multicolumn{4}{|c|}{ Mei } & \multicolumn{4}{|c|}{ Juni } & \multicolumn{4}{|c|}{ Juli } \\
\hline & & $\mathrm{i}$ & ii & iii & iv & i & ii & iii & iv & $\mathrm{i}$ & ii & iii & iv & $\mathrm{i}$ & ii & $\mathrm{iii}$ & iv & $\mathrm{i}$ & ii & iii & iv \\
\hline 1 & Persiapan alat dan bahan & & & & & & & & & & & & & & & & & & & & \\
\hline 2 & Perakitan alat instalasi & & & & & & & & & & & & & & & & & & & & \\
\hline 3 & Pengambilan data & & & & & & & & & & & & & & & & & & & & \\
\hline 4 & Pengolahan data & & & & & & & & & & & & & & & & & & & & \\
\hline 5 & Analisis dan pembahasan & & & & & & & & & & & & & & & & & & & & \\
\hline 6 & Penyusunan laporan pengujian & & & & & & & & & & & & & & & & & & & & \\
\hline
\end{tabular}

\section{Alur Pengujian}

Adapun alur pengujian yang akan dilakukan adalah seperti pada Gambar 1.

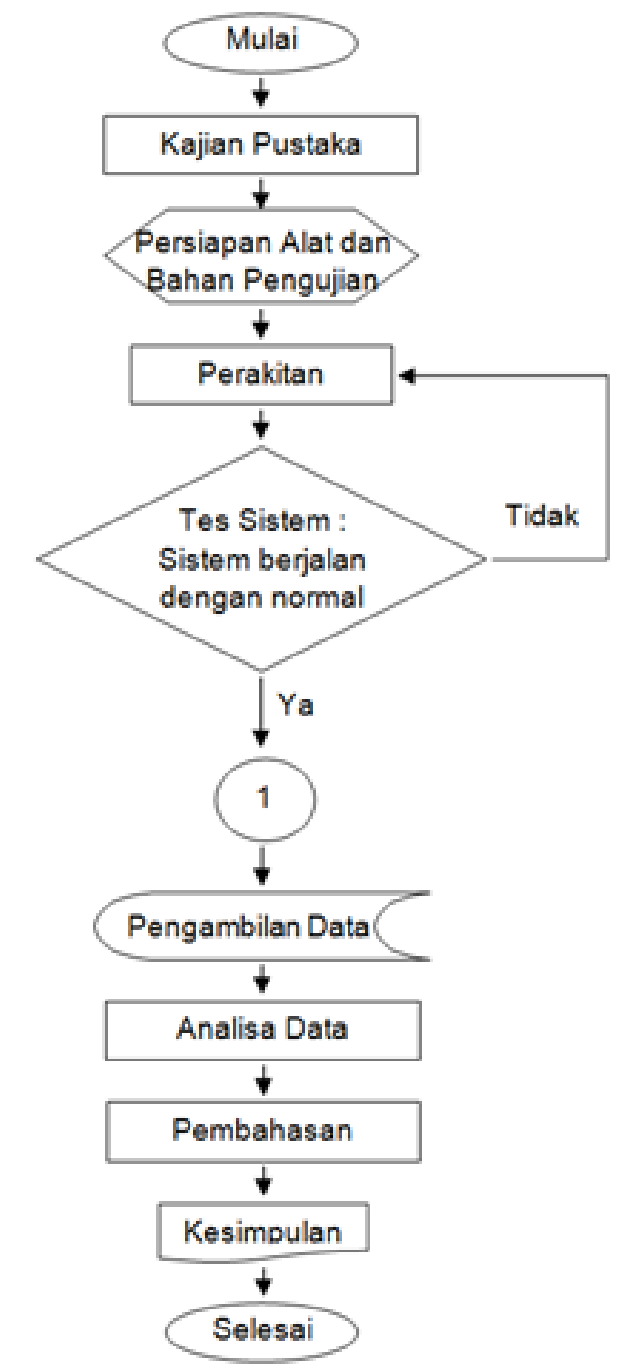

\section{Penentuan Sumber Data}

Ruang lingkup dalam pengujian adalah mencari nilai COP (Coefficient of Performance), EK (Efek Refrigerasi), Wk (Kerja Kompresor), dan daya kompresor (Watt).

Data yang diolah pada tabel pengujian adalah data pengujian dengan 5 debit yang berbeda yang diambil setiap 5 menit dan dilakukan sebanyak 10 kali pengujian, kemudian data-data tersebut dirata-ratakan terlebih dahulu agar bisa dilanjutkan ke perhitungan.

\section{Sumber Daya Penelitian}

Adapun alat pengujian yang digunakan dalam penelitian ini adalah simulator AC jenis Water Chiller (Gambar 2) yang ada di Laboratorium Tata Udara, Program Studi Teknik Pendingin dan Tata Udara Jurusan Teknik Mesin, dengan spesifikasi sebagai berikut :

- Kompresor hermetic 2PK merk Panasonic, jenis scroll, Kondensor fin and coil dengan pendinginan udara, Heat Recovery shell and coil dengan pendinginan air

- Evaporator Shell and Tube, FCU / Indoor Unit, Thermostatic

Expansion Valve, Pompa air

- Refrigeran yang digunakan adalah R-22

Gambar 1. Bagan Tahap Pelaksanaan 


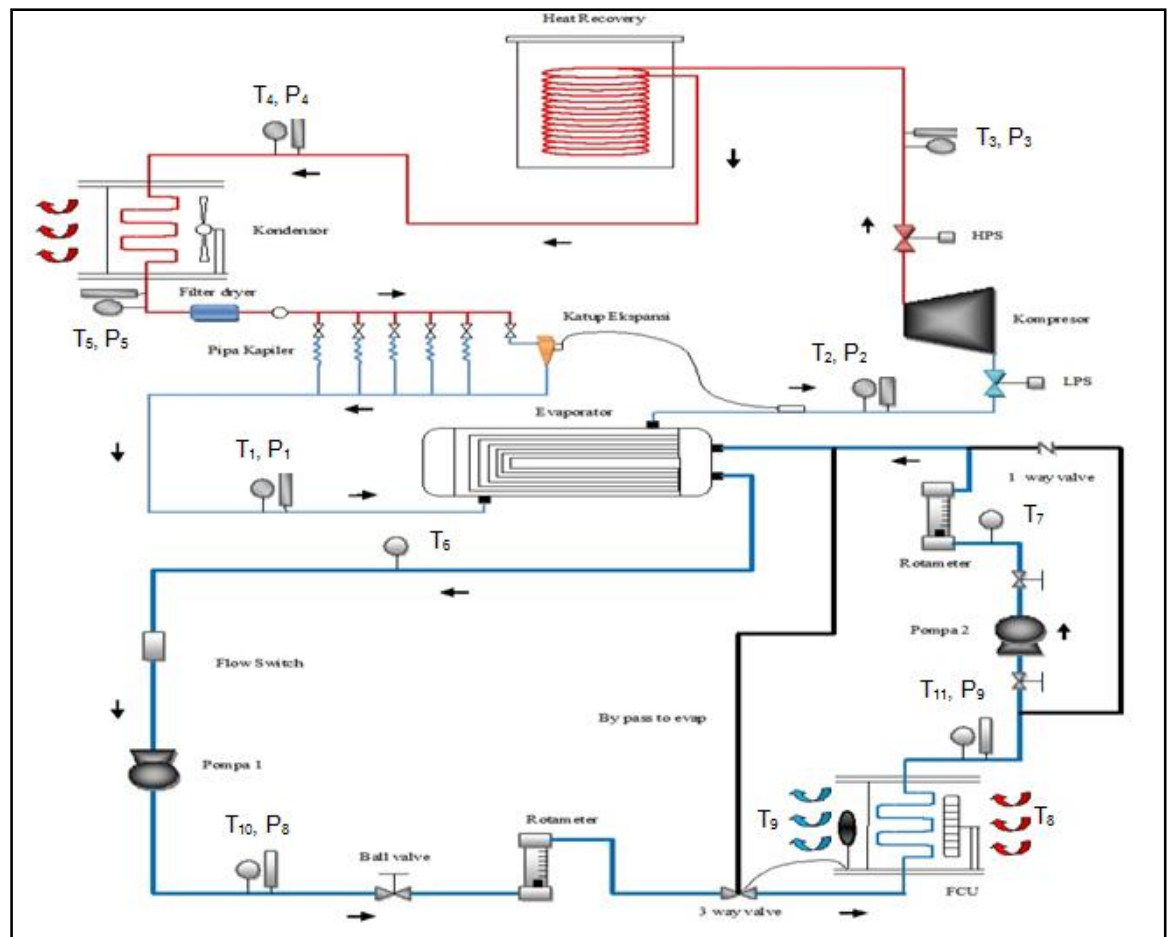

\section{Gambar 2. Skema Simulator AC Jenis Water Chiller}

\section{Instrumen Pengujianan}

Pada pengujian ini alat ukur yang digunakan untuk memperoleh data pengujian adalah sebagai berikut:

1. Thermocouple yaitu digunakan untuk mengukur temperature.

2. Gauge Manifold yaitu digunakan untuk mengukur tekanan refrigeran baik pada saat pemakuman, pengisian maupun pada saat beroperasi. Yang dapat dilihat pada gauge manifold adalah tekanan evaporator atau tekanan hisap (suction) kompresor dan tekanan kompresor atau tekanan keluar (discharge) kompresor.

3. Tang Amper yaitu digunakan untuk mengukur arus dan daya pada kompresor

4. Stop Watch yaitu untuk mengatur waktu yang dibutuhkan pada waktu pengambilan data atau pengujian.

Pengujian pada simulator AC jenis Water Chiller dengan menggunakan satu pompa dan dua pompa yang dirangkai seri dengan menggunakan TXV (Thermostatic Expansion Valve) di mana proses yang dilakukan dengan langkah sebagai berikut :

1. Mengoperasikan sistem dengan posisi "ON" pada selector switch kompresor dan pompa sirkulasi kemudian tekan tombol "START".

2. Membuka katup TXV (Thermostatic Expansion Valve), kemudian tutup katup pompa 2. Mengatur putar katup air rota meter pada nilai 11 LPM. Pastikan sistem berjalan normal dan biarkan sistem bekerja \pm 25 menit dan lakukan pengambilan data T1, T2, T3, T4, T5, T6, T7, T8, T9, T10, T11, T12, T13, P1, P2, P3, P4, P5, P6, P7, P8, P9, dan I kompresor sebanyak 5 kali dengan masing-masing durasi waktu 5 menit. Begitu juga saat rota meter pada nilai 12 LPM sampai dengan 15 LPM.

3. Kemudian buka katup pompa 2. Mengatur putar katup air rota 
meter pada nilai 11 LPM. Pastikan sistem berjalan normal dan biarkan sistem bekerja \pm 25 menit dan lakukan pengambilan data T1, T2, T3, T4, T5, T6, T7, T8, T9, T10, T11, T12, T13, P1, P2, P3, P4, P5, P6, P7, P8, P9, dan I kompresor sebanyak 5 kali dengan masing-masing durasi waktu 5 menit. Begitu juga saat rota meter pada nilai 12 LPM sampai dengan 15 LPM.

4. Setelah semua data didapat, matikan sistem dengan menekan tombol "STOP" dan matikan panel listrik.

5. Lalu kedua pengujian tersebut masuk keproses perhitungan.

\section{Perhitungan Menentukan Nilai Optimasi}

Di bawah ini akan dijelaskan prinsip kerja mesin refrigerasi kompresi uap. Mesin refrigerasi kompresi uap terdiri atas empat komponen utama, yaitu: kompresor, kondensor, alat ekspansi, dan evaporator. Kondensor dan evaporator merupakan alat peukar kalor yang berfungsi mempertukarkan kalor diantara dua fluida, yakni antara refrigeran dengan fluida luar (biasa berupa air atau udara). (Stoecker, 1994)

1. Proses kompresi $(1-2)$

Kondisi awal refrigeran pada saat masuk ke dalam kompresor adalah uap jenuh bertekanan rendah dan bertemperatur rendah, setelah uap refrigerant mengalami kompresi refrigeran akan menjadi uap bertekanan tinggi dan bertemperatur tinggi.

2. Proses kondensasi $(2-3)$

Proses ini berlangsung di kondensor. Refrigeran yang bertekanan tinggi dan bertemperatur tinggi yang keluar dari kompresor akan membuang kalor sehingga fasenya berubah menjadi refrigeran cair. Hal ini berarti bahwa di dalam kondensor terjadi pertukaran kalor antara refrigeran dengan lingkungannya (udara), sehingga panas berpindah dari refrigeran ke udara pendingin yang menyebabkan uap refrigeran mengembun menjadi cair.

3. Proses ekspansi $(3-4)$

Proses ekspansi ini berlangsug secara isoentalpi. Proses penurunan takanan pada saat ekspansi. Berfungsi untuk mengatur laju aliran refrigeran dan menurunkan tekanan.

4. Proses evaporasi $(4-1)$

Proses ini berlangsung secara isobar isothermal (tekanan konstan, temperature konstan) di dalam evaporator. Panas dari dalam ruangan akan diserap oleh cairan refrigeran yang bertenganan rendah sehingga refrigeran berubah fase menjadi uap bertekanan rendah. Kondisi refrigeran saat masuk evaporator.
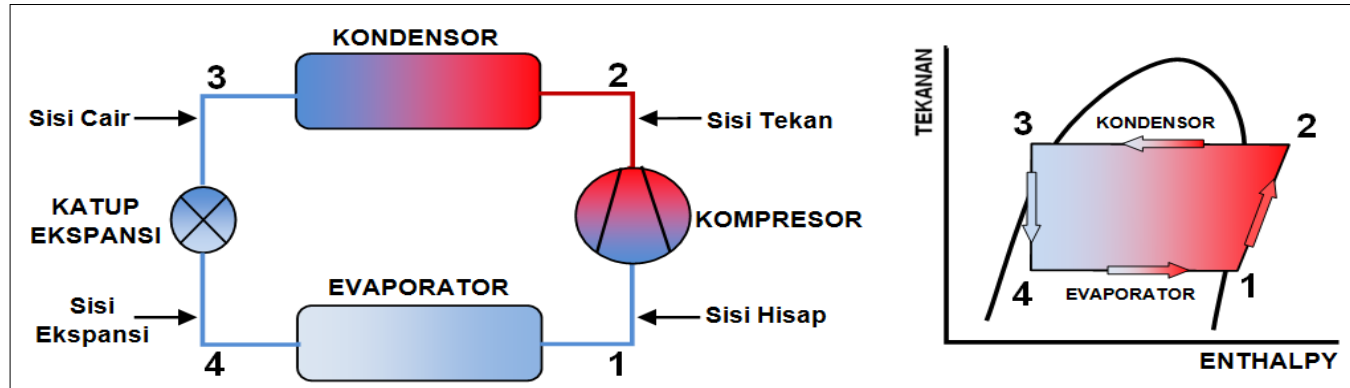

Gambar 3. Siklus Kompresi Uap 
Besarnya kerja kompresi (Wk) sama dengan selisih enthalpy uap refrigeran yang keluar kompresor dengan enthalpy uap refrigeran masuk ke kompresor pada proses $(1-2)$.

$W k=h_{2}-h_{1}(k j / k g)$

Keterangan :

Wk = kerja kompresor

$\mathrm{h}_{1} \quad=$ enthalpy uap refrigeran pada sisi hisap kompresor $(\mathrm{kj} / \mathrm{kg})$

$\mathrm{h}_{2} \quad=$ enthalpy uap refrigeran pada sisi buang kompresor (kj/kg)

Efek Refrigerasi (ER) adalah kalor yang diterima oleh sistem dari lingkungan melalui evaporator per satu massa laju refrigeran. Efek refrigerasi merupakan parameter penting, karena merupakan efek yang berguna dan diinginkan dari suatu sistem mesin pendingin. Besarnya efek refrigerasi tersebut adalah :

$E R=h_{1}-h_{4}(k j / k g)$

Keterangan :

$\mathrm{ER}=$ kerja kompresi

$\mathrm{h}_{4} \quad$ = enthalpy uap refrigeran yang masuk evaporator $(\mathrm{kj} / \mathrm{kg})$

Daya aktual dibutuhkan oleh kompresor untuk melakukan kerja kompresi dapat dihitung dengan rumus (Sinaga, 2006) :

$P=V \times I \times \cos \emptyset \quad$ (Watt $)$

Keterangan :

$\mathrm{V} \quad=$ tegangan (Volt)

$\mathrm{I}=$ arus (ampere)

$\operatorname{Cos} \emptyset$ yang digunakan adalah 0,9 Unjuk kerja atau dikenal dengan COP (coefficient of performance) menurut perbandingan antara kapasitas refrigerasi $(\mathrm{KR})$ dengan adanya $(\mathrm{Pk})$ yang dibutuhkan untuk menggerakkan kompresor. Untuk satu satuan massa refrigeran maka unjuk kerja dapat didefinisikan sebagai perbandingan antara efek refrigerasi (ER) sistem dengan kerja kompresor (Wk) yang dibutuhkan untuk mengkompresikan refrigeran di kompresor. Unjuk kerja merupakan parameter yang sangat penting di dalam sistem pendinginan, karena semakin besar harga unjuk kerja (COP) maka semakin baik kerja dari sistem pendinginan tersebut.

COP $=\frac{\mathrm{ER}}{\mathrm{Wk}}$

\section{HASIL DAN PEMBAHASAN}

\section{Hasil Penelitian}

Berdasarkan

pengujian perbandingan penggunaan satu pompa dan dua pompa yang dirangkai seri terhadap performansi simulator AC jenis water chiller menggunakan TXV (Thermostatic Expansion Valve) dengan memvariasikan laju aliran air yang berbeda-beda yaitu 11 LPM (Liter Per Menit), 12 LPM, 13 LPM, 14 LPM), dan 15 LPM pada simulator AC jenis water chiller.

Sehingga menghasilkan laju aliran massa air $0.18 \mathrm{~kg} / \mathrm{s}, 0.20 \mathrm{~kg} / \mathrm{s}$, $0.22 \mathrm{~kg} / \mathrm{s}, 0.23 \mathrm{~kg} / \mathrm{s}$, dan $0.25 \mathrm{~kg} / \mathrm{s}$ yang didapat melalui perhitungan sebagai contoh :

$$
\begin{aligned}
& 11 \mathrm{LPM}=0.000183 \mathrm{~m} 3 / \mathrm{s} \\
& \dot{\mathrm{m}} h=\rho h(\mathrm{~kg} / \mathrm{m} 3) \cdot \dot{V} h(\mathrm{~m} 3 / \mathrm{s}) \\
& =1,000 \frac{\mathrm{kg}}{\mathrm{m}^{3}} \times 0.000183 \frac{\mathrm{m}^{3} 3}{\mathrm{~s}} \\
& =0.18 \mathrm{~kg} / \mathrm{s}
\end{aligned}
$$

Maka diperoleh data-data yang disajikan pada Tabel 2.

Tabel 2. Data hasil rata-rata pengujian menggunakan satu pompa dan dua pompa 


\begin{tabular}{|c|c|c|c|c|c|c|c|c|c|c|c|c|}
\hline & \multicolumn{5}{|c|}{ Satu Pompa } & \multicolumn{5}{|c|}{ Dua Pompa } \\
\hline & & & 1 & 2 & 3 & 4 & 5 & 1 & 2 & 3 & 4 & 5 \\
\hline \multirow{2}{*}{$\begin{array}{l}\text { Out } \\
\text { Evap }\end{array}$} & P.1 & (psi) & 63 & 64 & 65 & 66 & 66 & 64 & 63 & 64 & 65 & 66 \\
\hline & $\mathrm{T} .1$ & $\left({ }^{\circ} \mathrm{C}\right)$ & 7 & 8 & 8 & 9 & 9 & 9 & 9 & 9.4 & 9.6 & 10.4 \\
\hline \multirow{2}{*}{$\begin{array}{c}\text { Out } \\
\text { Comp }\end{array}$} & P.2 & (psi) & 216 & 220 & 224 & 230 & 231 & 215 & 220 & 222 & 224 & 226 \\
\hline & Т.2 & $\left({ }^{\circ} \mathrm{C}\right)$ & 88.2 & 90 & 92 & 92.2 & 92.6 & 87 & 89 & 89 & 90 & 89 \\
\hline \multirow{2}{*}{$\begin{array}{c}\text { Out } \\
\text { Cond }\end{array}$} & P.3 & (psi) & 206 & 210 & 212 & 218 & 220 & 208 & 210 & 211 & 213 & 217 \\
\hline & T.3 & $\left({ }^{\circ} \mathrm{C}\right)$ & 40 & 40 & 40 & 39 & 40 & 39 & 37 & 38 & 38 & 39 \\
\hline \multirow{2}{*}{ Out HR } & P.4 & (psi) & 216 & 220 & 223 & 227 & 230 & 215 & 219 & 220 & 220 & 223 \\
\hline & T.4 & $\left({ }^{\circ} \mathrm{C}\right)$ & 43 & 50 & 55 & 59 & 62 & 42 & 48 & 53 & 57 & 59 \\
\hline \multirow{2}{*}{$\begin{array}{c}\text { Out } \\
\text { Exspansi }\end{array}$} & P.5 & (psi) & 71 & 71 & 72 & 73 & 74 & 71 & 69 & 72 & 72 & 73 \\
\hline & T.5 & $\left({ }^{\circ} \mathrm{C}\right)$ & 4 & 4 & 5 & 5 & 6 & 1.7 & 1.6 & 2 & 2.3 & 2.8 \\
\hline \multirow{2}{*}{$\begin{array}{l}\text { Water } \\
\text { Evap }\end{array}$} & T.6 & Out $\left({ }^{\circ} \mathrm{C}\right)$ & 12.5 & 12.6 & 13 & 13.2 & 13.4 & 12.7 & 12.6 & 12.8 & 12.8 & 13 \\
\hline & $\mathrm{T} .7$ & $\ln \left({ }^{\circ} \mathrm{C}\right)$ & 17.6 & 17.5 & 17.6 & 17.7 & 17.7 & 18 & 17.8 & 17.7 & 17.5 & 17.2 \\
\hline \multirow{2}{*}{ Air FCU } & T.8 & $\ln \left({ }^{\circ} \mathrm{C}\right)$ & 30 & 30.2 & 30.1 & 30.4 & 30.8 & 29.9 & 29.5 & 29.5 & 29 & 29.3 \\
\hline & Т.9 & $\operatorname{Out}\left({ }^{\circ} \mathrm{C}\right)$ & 20 & 20 & 20 & 20 & 20.3 & 20 & 19.7 & 19.6 & 19.5 & 19.3 \\
\hline \multirow{2}{*}{$\begin{array}{l}\text { Water } \\
\text { FCU }\end{array}$} & T.10 & $\ln \left({ }^{\circ} \mathrm{C}\right)$ & 14.1 & 14.4 & 14.5 & 14.8 & 15 & 14.3 & 15 & 14.5 & 14.7 & 15 \\
\hline & $\mathrm{T} .11$ & Out $\left({ }^{\circ} \mathrm{C}\right)$ & 16.6 & 16.7 & 16.7 & 17 & 17 & 16.8 & 16.6 & 17 & 14.4 & 16.2 \\
\hline \multirow{2}{*}{$\begin{array}{c}\text { Water } \\
\text { HR }\end{array}$} & T.12 & $\ln \left({ }^{\circ} \mathrm{C}\right)$ & 39 & 47 & 54 & 57 & 60.3 & 42.5 & 48.7 & 53.5 & 57.2 & 60.1 \\
\hline & $\mathrm{T} .13$ & Out $\left({ }^{\circ} \mathrm{C}\right)$ & 41 & 48.6 & 53 & 57.7 & 61 & 42.7 & 49 & 53.8 & 58 & 60.4 \\
\hline \multirow{2}{*}{$\begin{array}{l}\text { P water } \\
\text { Evap }\end{array}$} & P.6 & In (psi) & 0 & 0 & 0 & 0 & 0 & 1 & 2 & 2 & 4 & 5 \\
\hline & P.7 & Out(psi) & 0 & 0 & 0 & 0 & 0 & 0 & 0 & 0 & 0 & 0 \\
\hline \multirow{2}{*}{$\begin{array}{l}\text { P Water } \\
\text { FCU }\end{array}$} & P.8 & In (psi) & 9 & 10.2 & 12 & 14 & 16.1 & 1 & 2 & 3 & 4 & 5 \\
\hline & P.9 & $\begin{array}{l}\text { Out } \\
\text { (psi) }\end{array}$ & 1.5 & 2 & 2 & 2 & 2.5 & 0 & 0 & 0 & 0 & 0 \\
\hline \multirow{2}{*}{ RH FCU } & In & $(\%)$ & 53 & 53 & 53 & 53 & 53 & 53 & 53 & 53 & 53 & 53 \\
\hline & Out & (\%) & 86.8 & 86.8 & 86.8 & 86.8 & 86.8 & 86.8 & 86.8 & 86.8 & 86.8 & 86.8 \\
\hline \multicolumn{2}{|c|}{ Volt } & $(\mathrm{V})$ & 220 & 220 & 220 & 220 & 220 & 220 & 220 & 220 & 220 & 220 \\
\hline \multicolumn{2}{|c|}{ Ampere Comp } & (A) & 5.8 & 6 & 6 & 6 & 6 & 5.8 & 5.9 & 6 & 6 & 6 \\
\hline \multicolumn{2}{|c|}{ Flow Air } & $(\mathrm{m} / \mathrm{s})$ & 4 & 4 & 4 & 4 & 4 & 4 & 4 & 4 & 4 & 4 \\
\hline \multicolumn{2}{|c|}{ Flow Water } & Ipm & 11 & 12 & 13 & 14 & 15 & 11 & 12 & 13 & 14 & 15 \\
\hline
\end{tabular}

\section{Pembahasan}

Berdasarkan nilai data rata-rata yang telah diperoleh dari hasi pengujian pada simulator AC jenis Water Chiller, maka data tersebut dapat dimasukkan kedalam rumus untuk mendapatkan COP (Coefficient Of Performance) dan daya kompresor dari sistem. Berikut perhitungan dalam mencari COP (Coefficient Of Performance) dan daya kompresor pada masing-masing hasil pengujian.

Dari data hasil dapat dicari daya kompresor dan COP (Coefficient Of Performance) dari sistem.

a) Daya kompresor (Watt)

$$
\begin{aligned}
\rho & =\text { V.I.Cos } \phi \\
& =220 \times 5.8 \times 0.9 \\
& =1,148 \text { Watt }
\end{aligned}
$$


b) COP (Coefficient Of

Performance)

ER (Efek Refrigerasi) $\mathrm{kj} / \mathrm{kg}$

$E R=h_{1}-h_{4}$

$=409.635-247.191 \mathrm{kj} / \mathrm{kg}$

$=162.444 \mathrm{kj} / \mathrm{kg}$

WK (Kerja Kompresi) kj/kg

$\mathrm{WK}=\mathrm{h}_{2}-\mathrm{h}_{1}$

$=459.273-409.635 \mathrm{kj} / \mathrm{kg}$

$=49.638 \mathrm{kj} / \mathrm{kg}$

$$
\begin{aligned}
\text { COP }(\text { Unjuk Kerja) } \\
\begin{aligned}
\text { COP } & =\frac{\text { ER }(\text { Efek Refrigerasi })}{\text { WK }(\text { Kerja Kompresi })} \\
& =\frac{162.444 \mathrm{kj} / \mathrm{kg}}{49.638 \mathrm{kj} / \mathrm{kg}} \\
& =3.27
\end{aligned}
\end{aligned}
$$

Tabel 2. Data hasil perhitungan menggunakan satu pompa

\begin{tabular}{|c|c|c|c|c|c|c|}
\hline \multicolumn{2}{|c|}{} & 1 & 2 & 3 & 4 & 5 \\
\hline$\dot{\mathrm{m}}_{\mathrm{w}}$ & $(\mathrm{kg} / \mathrm{s})$ & 0.18 & 0.20 & 0.22 & 0.23 & 0.25 \\
\hline Daya & $($ Watt) & 1,148 & 1,188 & 1,188 & 1,188 & 1,188 \\
\hline ER & $\mathrm{kj} / \mathrm{kg}$ & 162.444 & 162.996 & 163.342 & 165.186 & 163.608 \\
\hline WK & $\mathrm{kj} / \mathrm{kg}$ & 49.638 & 50.134 & 51.674 & 50.613 & 51.091 \\
\hline \multicolumn{2}{|c|}{ COP } & 3.27 & 3.25 & 3.16 & 3.26 & 3.2 \\
\hline
\end{tabular}

Tabel 5. Tabel Data Hasil Perhitungan Menggunakan Dua Pompa

\begin{tabular}{|c|c|c|c|c|c|c|}
\hline \multicolumn{2}{|c|}{} & 1 & 2 & 3 & 4 & 5 \\
\hline$\dot{\mathrm{m}}_{\mathrm{w}}$ & $(\mathrm{kg} / \mathrm{s})$ & 0.18 & 0.20 & 0.22 & 0.23 & 0.25 \\
\hline Daya & $($ Watt $)$ & 1,148 & 1,168 & 1,188 & 1,188 & 1,188 \\
\hline ER & $\mathrm{kj} / \mathrm{kg}$ & 164.306 & 167.795 & 166.884 & 166.982 & 165.484 \\
\hline WK & $\mathrm{kj} / \mathrm{kg}$ & 47.287 & 48.449 & 48.077 & 48.626 & 47.36 \\
\hline \multicolumn{2}{|c|}{ COP } & 3.47 & 3.46 & 3.47 & 3.43 & 3.49 \\
\hline
\end{tabular}

Dari hasil perhitungan yang telah dilakukan terhadap sistem maka didapatkan beberapa hasil dari pengolahan data dan hubungan grafik dari penggunaan TXV (Thermostatic Expansion Valve). Hubungan grafik tersebut meliputi Daya kompresor (kw), ER (Efek Refreigerasi), WK (Kerja Kompresi), dan COP (Coefficient Of
Performance), terhadap persentasi laju aliran massa air mulai dari $0.18 \mathrm{~kg} / \mathrm{s}$, $0.20 \mathrm{~kg} / \mathrm{s}, 0.22 \mathrm{~kg} / \mathrm{s}, 0.23 \mathrm{~kg} / \mathrm{s}$, dan 0.25 $\mathrm{kg} / \mathrm{s}$ menggunakan satu pompa dan dua pompa yang dirangkai seri. Dari hasil perhitungan yang diperoleh maka didapatkan grafik seperti pada gambar 4.

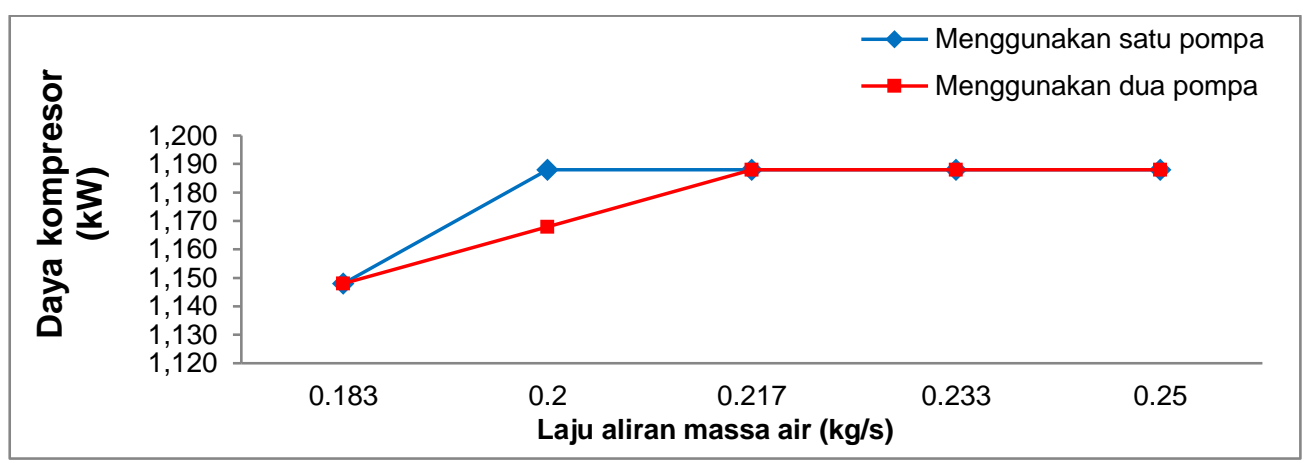

Gambar 4. Grafik Perbandingan Daya Kompresor 
Dari gambar 4 saat menggunakan satu pompa, semakin besar laju aliran massa air maka ada kecendrungan daya kompresor yang dibutuhkan semakin besar. Karena air yang masuk ke evaporator semakin cepat, sehingga beban pendinginan semakin besar. Begitu juga saat menggunakan dua pompa, semakin besar laju aliran massa air maka daya kompresor yang dibutuhkan juga semakin besar.

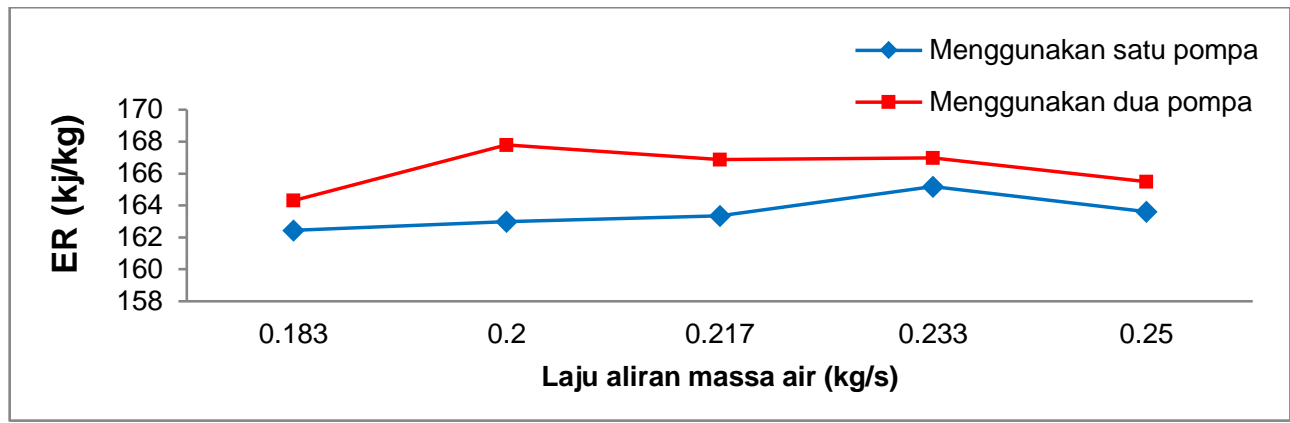

Gambar 5. Grafik Perbandingan ER (Efek Refrigerasi)

Dari gambar 5 saat menggunakan dua pompa hasil ER (Efek Refrigerasi) lebih besar dibandingkan menggunakan satu pompa. Karena saat menggunakan dua pompa, refrigeran menyerap lebih banyak panas dari air evaporator

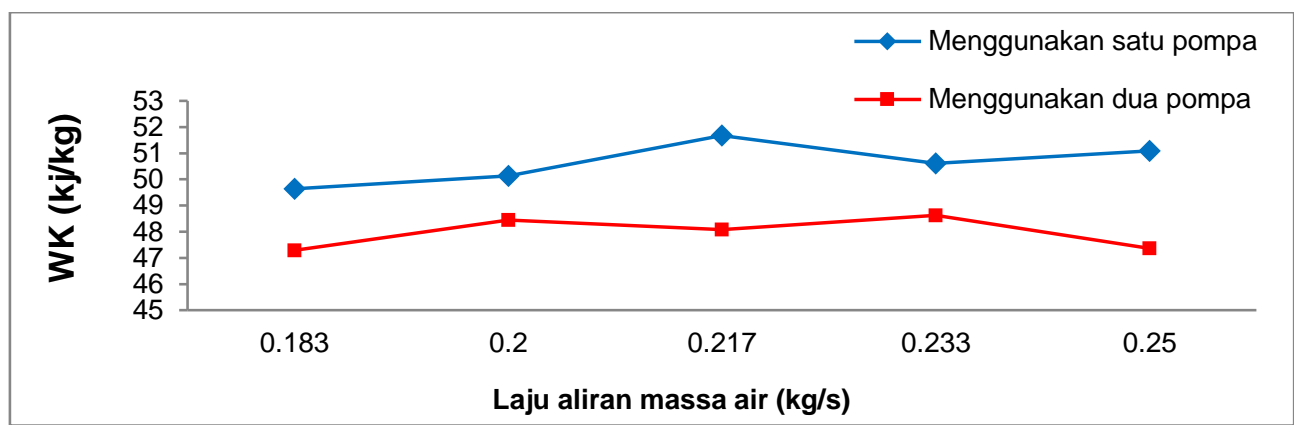

Gambar 6. Grafik Perbandingan WK (Kerja Kompresi)

Dari gambar 6 saat menggunakan satu pompa hasil WK (Kerja Kompresi) lebih besar dibandingkan menggunakan dua pompa. Karena saat menggunakan satu pompa, laju aliran massa air yang masuk ke evaporator kurang efisien maka dari itu kinerja kompresor yang dibutuhkan menjadi lebih besar.

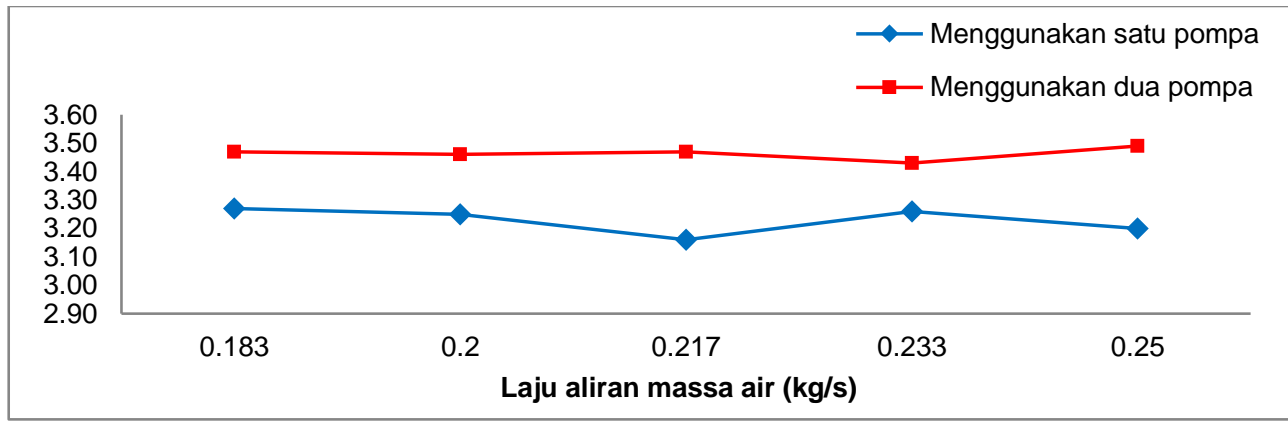

Gambar 7. Grafik Perbandingan Performansi Sistem (COP) 
Dari gambar 7 saat menggunakan dua pompa hasil COP (Coefficient Of Performance) lebih bagus dibandingkan menggunakan satu pompa. Karena saat menggunakan dua pompa, adanya konveksi paksa.

\section{PENUTUP}

\section{Kesimpulan dan Saran}

Dari hasil pengujian perbandingan menggunakan satu pompa dan dua pompa yang dirangkai seri dengan variasi laju aliran massa air yang berbeda pada simulator AC jenis water chiller dapat disimpulkan sebagai berikut:

1. Adanya kenaikan daya yang dibutuhkan kompresor sebesar $3.47 \%$ dengan laju aliran massa air pada saat menggunakan satu pompa maupun dua pompa karena air yang masuk ke evaporator semakin cepat sehingga beban pendinginan semakin besar.

2. Penggunaan dua pompa lebih baik dibandingkan satu pompa dikarenakan adanya konveksi paksa. Sehingga dapat meningkatkan COP sebesar $6.25 \%$. Ketelitian dalam pengukuran sangat diperlukan untuk mendapatkan hasil perhitungan yang baik, sehingga mendekati nilai COP maupun Daya yang sebenarnya.

\section{DAFTAR PUSTAKA}

1. Daryanto. (2014). Konsep Dasar Teknik Elektronika Kelistrikan, Bandung: ALFABETA

2. Duta Jaya Service. Motor Listrik (Motor Fan dan Motor Blower). https://goo.gl/images/8Wwrjx (Diakses pada tanggal 22 Januari 2018).

3. Hara. S. 1994. Refrigerasi dan Pengkondisian Udara. Erlangga. Jakarta.
4. Midiani. L. P. I. 2015. Simulasi AC Domestik. Program Studi Teknik Pendingin dan Tata Udara. Politeknik Negeri Bali. Badung-Bali.

5. Prasetyono. D. S. 2003. Pedoman Langkah Teknik Memperbaiki Kulkas \& AC. ABSOLUT. Yogyakarta.

6. Rasta. I. M. 2009. Pengaruh Laju Aliran Volume Chilled Water Terhadap NTU pada FCU Sistem AC Jenis Water Chiller. 72.

7. Suamir. I. N. 2015. Teknologi Refrigerasi. Program Studi Teknik Pendingin dan Tata Udara. Politeknik Negeri Bali. Badung-Bali.

8. Sumanto. 2000. Dasar-Dasar Mesin Pendingin. Edisi 1. ANDI. Yogyakarta-Indonesia.

9. Tampubolon. D. Samosir. R. 2005. Pemahaman Tentang Sistem Refrigerasi. 314-317.

10. Stoecker, W.F. \& Jerold J.W. (1994). Refrigerasi dan Tata Udara edisi kedua,PT. Erlangga, Jakarta

11. Widodo, S., Syamsuri Hasan. (2008) Refrigerasi dan Tata Udara, Jakarta: Departemen Pendidikan Nasional. 